\author{
ІМПЛЕМЕНТАЦІЯ ЕКОЛОГІЧНОГО МАРКЕТИНГУ \\ В ПРАКТИЧНУ ДІЯЛЬНІСТЬ АГРАРНИХ ПІДПРИЕМСТВ \\ IMPLEMENTATION OF ECOLOGICAL MARKETING \\ IN THE PRACTICAL ACTIVITIES OF AGRARIAN ENTERPRISES
}

УДК 339.138

DOI: https://doi.org/10.32843/bses.48-30

\section{Багорка М.O.}

д.е.н., доцент касредри маркетингу

Дніпровський державний

аграрно-економічний університет

\section{Bahorka Mariia}

Dnipro State Agrarian

and Economic University
У статті запропоновано маркетинговий інструментарій для імплементації екологічного маркетингу в діяльність аграрних підприємств задля підвищення їх конкурентоспроможності відповідно до нових сучасних трендів економічного, екологічного й соціального розвитку. Встановлено, що екологічно орієнтований комплекс маркетингу в аграрному виробництві включає фрормування методів ціноутворення, розбудову ринкової інфрраструктури, оптимізацію витрат на виробництво органічної продукції за умов державної підтримки агровиробників, розширення каналів реалізації та засобів просування органічної продукції та залежить від впливу зовнішніх та внутрішніх фракторів, виду продукції і мотивування споживачів. Всі елементи екологічно орієнтованого комплексу маркетингу мають бути взаємоузгоджені, адаптовані та доповнені з урахуванням екологічних вимог, потреб потенційних споживачів. Обірунтовано нові підходи маркетингової збутової політики аграрних підприємств з виробництва органічної продукції, які засновані на переорієнтації до потреб ринку.

Ключові слова: екологічний маркетинг, маркетингові стратегії, аграрні підприємства, маркетинговий інструментарій, органічна продукція, збутова політика, сертифрікація.

B cтатье предложен маркетинговый инструментарий для имплементации эко- логического маркетинга в деятельность аграрных предприятий с целью повышения их конкурентоспособности в соответствии с новыми современными трендами экономического, экологического и социального развития. Установлено, что экологически ориентированный комплекс маркетинга в аграрном производстве включает формирование методов ценообразования, развитие рыночной инфраструктуры, оптимизацию затрат на производство органической продукции в условиях государственной поддержки агропроизводителей, расширение каналов реализации и способов продвижения органической продукции и зависит от влияния внешних и внутренних фракторов, вида продукции и мотивации потребителей. Все элементы экологически ориентированного комплекса маркетинга должны быть взаимосогласованными, адаптированными и дополненными с учетом экологических требований, потребностей потенциальных потребителей. Обоснованы новые подходы маркетинговой сбытовой политики аграрных предприятий по производству органической продукции, основанные на переориентации к потребностям рынка.

Ключевые слова: экологический маркетинг, маркетинговые стратегии, аграрные предприятия, маркетинговый инструментарий, органическая продукция, сбытовая политика, сертифрикация.

The article offers marketing tools for the implementation of environmental marketing in the activities of agricultural enterprises, with the aim of increasing their competitiveness in accordance with new modern trends in economic, environmental and social development. It is established that ecologically oriented complex of marketing in agrarian production includes formation of methods of pricing, development of market infrastructure, optimization of costs for production of organic products under conditions of state support of agricultural producers, expansion of channels of sale and means of promotion of organic production and depends on the influence of external and internal products, and consumer motivation. It is established that the process of pricing for organic products should take into account the specifics of demand, supply, level of competition, as well as the interests of producers of products. Price should promote the development of agricultural enterprises in the transition from traditional to organic production and as a result expand the production of organic products. Implementation of the concept of eco-marketing to provide high quality products, which will accordingly be accompanied by an increase in its cost and price. All elements of an eco-oriented marketing complex must be mutually consistent, adapted and complemented to meet the environmental requirements and needs of potential consumers. New approaches of marketing policy of agricultural enterprises for organic production are grounded, based on reorientation to market needs. More progressive forms of marketing are proposed: active activity of organic producers in the wholesale markets; direct sale of high quality eco-products based on the principles of exclusive distribution and with the involvement of specialized intermediaries; creation of new marketing structures - vertically and horizontally integrated marketing systems and cooperatives. Integrated interaction with government agencies and processing enterprises will increase innovation and investment in organic production.

Key words: ecological marketing, marketing strategies, agricultural enterprises, marketing tools, organic products, marketing policy, certification.

Постановка проблеми. В умовах глобалізації світової економіки, загрози екологічної та продовольчої кризи головним аспектом стратегії ефективного управління аграрною галуззю є задоволення постійно зростаючого попиту на продукти харчування та оздоровлення населення за нарощування обсягів валового виробництва екологічно безпечної продукції. Майже всі країни світу намагаються змен- шити забруднення довкілля й зробити виробництво продуктів харчування більш екологічним.

Сільське господарство належить до найбільш впливових на довкілля секторів економіки України, бо воно організовує своє виробництво на великих територіях. Водночас, незважаючи на наявний природно-ресурсний потенціал, сприятливі кліматичні умови, внаслідок дії окремих суспільних, політичних 
та екологічних фракторів і трендів відбуваються зменшення обсягів виробництва сільськогосподарської продукції та значне погіршення ії̈ якості. Протягом багатьох років екологічна ситуація в Україні визначається як кризова, що перш за все негативно позначається на якості продукції та здоров'ї людини. Причиною цього є довготривалий процес інтенсифрікації виробництва в аграрній сорері економіки, який має не лише позитивні, але й негативні наслідки для галузі. Останніми роками цей процес зумовив загострення екологічної кризи й створив низку проблем екологічного характеру, які ставлять під сумнів правильність сучасної системи господарювання.

Продовольчий ринок України з органічної продукції за багатьма позиціями перебуває на етапі становлення й характеризується надлишковою пропозицією за умов незначного внутрішнього попиту. Основним трендом сучасності $€$ те, що більша частка виробленої органічної продукції експортується переважно на європейський ринок. Одними 3 головних причин такого становища (разом 3 недосконалим правовим полем, низьким рівнем купівельної спроможності населення, недосконалою розбудовою ринкової інфрраструктури) $є$ недостатній рівень розроблення та імплементації екологічного маркетингу в діяльність аграрних підприємств 3 виробництва органічної продукції як на внутрішньому, так і на зовнішньому ринках, дослідження попиту, потреб та особливостей поведінки споживачів органічної продукції, комплексного та ситуаційного аналізу маркетингового середовища й кон'юнктури ринку, відповідно, розроблення ефрективної концепції екологічного маркетингу для аграрних підприємств. Саме це обумовило необхідність дослідження питання впровадження екологічного маркетингу в практичну діяльність аграрних підприємств України.

Аналіз останніх досліджень і публікацій. Екологічні та економічні аспекти функціонування сільськогосподарських підприємств досліджено в працях В.А. Борисової, П.С. Березівського, Н.В. Зіновчука, О.М. Царенка; проблеми фрормування й встановлення ресурсо-екологічної та продовольчої безпеки досліджували П.А. Лайко, Л.Г. Мельник, В.М. Трегобчук; фрінансово-економічне забезпечення підприємств в аграрній сорері досліджували О.Л. Кашенко, А.В. Чупас та інші науковці.

Наукові розробки щодо теоретичних і прикладних аспектів розвитку ринку органічної продукції належать вітчизняним вченим, зокрема B.І. Артишу, Р.М. Безусу, Н.В. Бородачевій, Є.В. Гавазі, Н.В. Зіновчук, М.І. Кобцю, Л.Ц. Масловській, Є.В. Милованову, Н.П. Новак, О.В. Скидану, Т.О. Чайці, О.В. Шубравській, О.М. Яценко.

Водночас наукові положення щодо впровадження концепції екологічного маркетингу в практичну діяльність аграрних підприємств потребують подальшого вивчення.
Ми переконані в тому, що знати теоретичні концепції маркетингу та мати певні ідеї ведення бізнесу в аграрному секторі економіки недостатньо. Важливо сорормувати маркетинговий інструментарій, в основі якого має лежати сукупність способів, методів, критеріїв, які допоможуть впливати на споживачів, задля забезпечення населення екологічно безпечними продуктами харчування. Для нас $€$ важливим пошук саме маркетингових механізмів та інструментів підвищення ефективності діяльності підприємств аграрної сорери виробництва на основі посилення екологічної спрямованості.

Постановка завдання. Метою статті $€$ розроблення практичних рекомендацій щодо фрормування маркетингового інструментарію для імплементації екологічного маркетингу в діяльність аграрних підприємств.

Виклад основного матеріалу дослідження. Ключовою проблемою на сучасному етапі розвитку країни є екологічне вдосконалення економічної діяльності, що передбачає зниження потреби залучення природних ресурсів до виробництва, а також дотримання екологічної рівноваги між споживанням природних ресурсів аграрним сектором та можливістю природного середовища щодо їх відновлення. Необхідно також забезпечити сталий розвиток аграрного виробництва шляхом ефективного використання ресурсного потенціалу сільського господарства та запровадження екологічно спрямованої системи управління, сутність якої полягає у встановленні та підтримці балансу між інтересами сільськогосподарського товаровиробника та екологічним станом навколишнього середовища [1, с. 215].

Важливо розуміти, що екологічний маркетинг принципово відрізняється від інших маркетингових концепцій тим, що націлений на отримання екологічного результату від запровадження певного набору інструментів на рівні із задоволенням потреб споживачів та прибутковістю діяльності підприємств.

Для аграрного сектору економіки фрункціонування системи екологічного маркетингу є цілком реальним процесом, який передбачає інтеграцію всіх функцій системи управління, виявлення, планування та прогнозування розвитку екологічно спрямованих ініціатив керівників аграрних підприємств на інноваційно-інвестиційній основі, що пов'язані з виробництвом, фрормуванням та стимулюванням попиту на екологічно безпечну продукцію й послуги. Впровадження концепції екологічного маркетингу пов'язано з реалізацією системи екологічного менеджменту.

Процес поступового розвитку органічного виробництва в Україні відбувається досить високими темпами. Важливу роль відіграє питання відповідності національного законодавства міжнародному, що уніфрікує такі відносини та дає змогу 
будувати їх на взаємовигідній основі. Такими законодавчими документами є міжнародний проєкт «Доступ до глобального органічного ринку» (Global Organic Market Access, GOMA), що фрормує основи запровадження єдиних органічних стандартів і вимог сертифрікації; Інструкція з оцінки еквівалентності стандартів і технічних регламентів (Equi Tool); Міжнародні вимоги до органічних сертисрікаційних організацій (IROCB) [2].

Виробництво екологічно чистої продукції АПК це багатофункціональний агроекологічний процес, що базується на ретельному управлінні агроекосистемами на соціальному, екологічному та економічному рівнях [3, с. 162].

Наявність в Україні значної кількості сертифрікаційних органів, об'єднань виробників стимулює розвиток вітчизняного органічного ринку. За даними Міжнародної фредерації органічного сільськогосподарського руху (IFOAM) та Дослідного інституту органічного сільського господарства (FiBL) у 2017 р. під органічним землеробством в Україні було задіяно 420 тис. га сільськогосподарських угідь, що становить приблизно 1\% від загальної площі угідь, фрункціонували 375 «органічних» господарств із середнім розміром 2150 гектарів. Існує чітка тенденція зростання розміру земель, зайнятих під органічним виробництвом, та кількості сертиорікованих виробників.

Треба зауважити, що більшість аграрних підприємств перебуває в конверсійному періоді, який може тривати від 2 до 5 років і супроводжуватися окремими ризиками.

Після проходження конверсійного періоду аграрні підприємства мають розпочати процес сертифрікації виробництва органічної продукції. Одразу треба зазначити, що цей процес $є$ тривалим і фрінансово затратним.
Сертифрікацію органічного виробництва в Україні здійснюють такі компанії:

- представництво компанії «Control union Ukraine» (Нідерланди), що проводить сертифікацію відповідно до Постанови ЄС № 834/2007 та № 889/2008;

- компанія «Органік стандарт», що є лідером у галузі стандартизації органічного виробництва в Україні.

Іноземні компанії, які можуть брати участь у сертифрікації українських аграрних підприємств, та вартість їх послуг наведено в табл. 1.

Ми переконані, що переходити на органічне виробництво й замовляти сертифрікацію варто тільки за наявності обґрунтованої маркетингової стратегії збуту органічної продукції та ринкового зростання аграрного підприємства.

Для впровадження концепції екологічного маркетингу в діяльність аграрних підприємств необхідно сорормувати маркетинговий інструментарій, в основі якого мають лежати продукт, ціна, просування й розподіл, тобто основні складові елементи комплексу 4Р; з позиції споживача - потреби, витрати, комунікація й зручність. На відміну від традиційної системи інструментів комплексу маркетингу, вищезазначені враховують екологічні аспекти. Відзначимо, що екологічна компонента присутня в кожному з чотирьох елементів комплексу маркетингу (рис. 1).

Формування оптимального товарного портфеля передбачає наявність певного обсягу кількості товару, що перебувають на різних стадіях життєвого циклу, а також дає змогу забезпечити збалансоване зростання підприємства з найменшими ризиками. Підприємство має спрямовувати зусилля на збільшення не тільки обсягу продажів, але й частки ринку, а також прагнути домінування на вибраних ринкових сегментах.

\section{Сертифрікаційні іноземні структури та вартість їх послуг в Україні}

Таблиця 1

\begin{tabular}{|c|c|}
\hline $\begin{array}{l}\text { Назва органу } \\
\text { сертифікації, країна }\end{array}$ & Вартість послуг \\
\hline ABCERT, Німеччина & $\begin{array}{l}\text { Мінімальна плата контролю (одноразове) для виробників становить } 195 \text { євро, а мак- } \\
\text { симальна - } 440 \text { євро на рік. Одноразова сума включає певну кількість часу перевірки. } \\
\text { Якщо цей час перевищено, додатковий час оплачується як } 65 \text { євро на годину. }\end{array}$ \\
\hline Bio Garantie. Австрія & $\begin{array}{l}\text { Основний внесок становить } 90 \text { євро. Змінні витрати такі: для пасовищ - 6,60 євро/га, орні } \\
\text { поля - 7,81 євро/га, спеціальні культури (вино, ягоди тощо) - 14,13 євро/га. Мінімальна } \\
\text { плата контролю (одноразово) для виробників становить } 195 \text { євро, а максимальна - } \\
440 \text { євро на рік. }\end{array}$ \\
\hline ICEA, Італія & $\begin{array}{l}\text { Фіксована плата становить від } 50 \text { до } 180 \text { євро/рік + змінні витрати залежно від площі та } \\
\text { типу культур. Змінний внесок становить від } 10 \text { до } 200 \text { євро/га. Разом мінімальні змінні } \\
\text { витрати становлять } 200 \text { євро, максимальний змінний внесок - } 7000 \text { євро. }\end{array}$ \\
\hline Suolo e Salute, Італія & $\begin{array}{l}\text { Замовник повинен заповнити форму на сайті, щоб отримати визначення ціни сертисрікації } \\
\text { та інспекції. Існує фріксований збір у розмірі } 80 \text { євро/рік. }\end{array}$ \\
\hline LaCon, Німеччина & 560 євро/день + адміністративні та транспортні витрати. \\
\hline Biogricept, Італія & $\begin{array}{l}\text { Річний внесок становить 190-360 євро/рік + 2,60 євро/га залежно від типу вирощуваних } \\
\text { культур. }\end{array}$ \\
\hline ETKO, Туреччина & євро/день; вартість варіюється залежно від розміру. \\
\hline
\end{tabular}

Джерело: узагальнено автором 


\begin{tabular}{|c|c|c|}
\hline 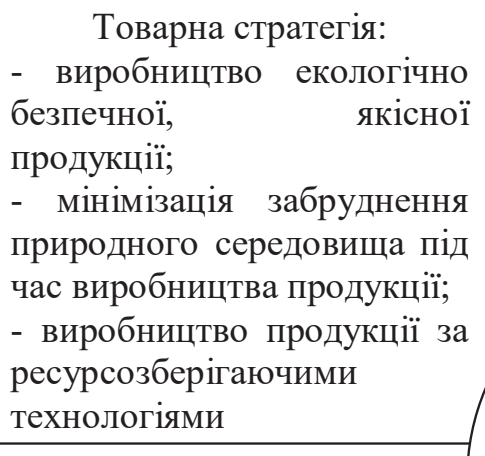 & $\begin{array}{l}\text { Маркетинговий } \\
\text { інструментарій } \\
\text { впровалженнн }\end{array}$ & $\begin{array}{l}\text { Збутова стратегія: } \\
\text { - формування каналів збуту } \\
\text { екологічно безпечної } \\
\text { продукції, а саме прямих, } \\
\text { непрямих, змішаних } \\
\text { - спеціалізовані канали } \\
\text { збуту екологічно безпечної } \\
\text { продукції }\end{array}$ \\
\hline $\begin{array}{l}\text { Цінова стратегія: } \\
\text { - цінова диференціація; } \\
\text { - обгрунтування цінової } \\
\text { надбавки за екологічність; } \\
\text { - розрахунок собівартості } \\
\text { продукції; } \\
\text { - вигідні цінові пропозиції з } \\
\text { боку держави для } \\
\text { виробників екологічно } \\
\text { безпечної продукції }\end{array}$ & $\begin{array}{c}\text { екологічного } \\
\text { маркетингу }\end{array}$ & 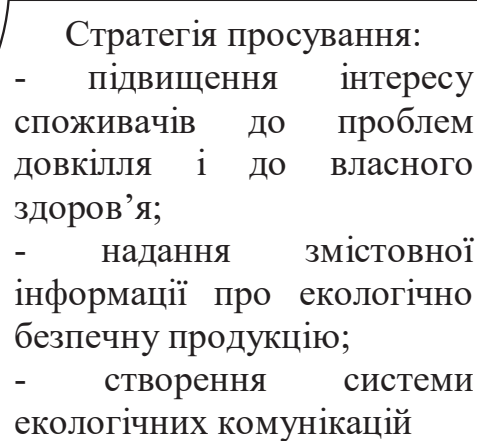 \\
\hline
\end{tabular}

Рис. 1. Основні складові впровадження концепції екологічного маркетингу

Джерело: срормовано автором

Аналіз товарної політики посідає важливе місце в маркетинговій діяльності підприємства, адже від його результатів залежать визначення потенційних можливостей, розроблення відповідних програм маркетингу, координація сукупності товарів відповідно до вимог ринку та вподобань споживачів.

Для більшості аграрних підприємств пропонуємо такий товарний порторель з відповідними маркетинговими стратегіями (табл. 2).
Вітчизняна практика свідчить про те, що кількість та обсяги виробництва органічної продукції займають малу частку й не відповідають потребам населення. Основна причина полягає в тому, що сьогодні не кожен виробник має можливість здійснювати додаткові поточні й капітальні витрати на виробництво органічної продукції. Під час формування ціни на органічну продукцію виробник аграрної продукції має розуміти розмір витрат

Таблиця 2

Альтернативні маркетингові стратегій для основних видів продукції

\begin{tabular}{|c|c|c|}
\hline $\begin{array}{c}\text { Назва } \\
\text { продукції }\end{array}$ & Характеристика позиції & Альтернативні маркетингові стратегії \\
\hline Молоко & $\begin{array}{l}\text { Найвигідніше становище } \\
\text { бізнесу. Продукт діє на } \\
\text { дуже перспективному } \\
\text { ринку збуту й має на ньому } \\
\text { сильні конкурентні позиції. }\end{array}$ & $\begin{array}{l}\text { Стратегія підтримання конкурентних переваг така: зниження цін та } \\
\text { застосування системи знижок для оптових покупців, розвиток системи } \\
\text { збуту, максимізація інвестицій, розширення виробництва. }\end{array}$ \\
\hline $\begin{array}{l}\text { Соняшник, } \\
\text { м'ясо } \\
\text { свиней }\end{array}$ & $\begin{array}{c}\text { Висока привабливість } \\
\text { ринку та середня } \\
\text { конкурентоспроможність } \\
\text { продукції. } \\
\end{array}$ & $\begin{array}{l}\text { Стратегія зростання (збільшення частки ринку) така: інтенсифрікація } \\
\text { маркетингових зусиль на просування, пошук нових каналів збуту, підви- } \\
\text { щення якості та процесу виробництва, вдосконалення цінової політики, } \\
\text { збільшення конкурентоспроможності продукції. }\end{array}$ \\
\hline $\begin{array}{l}\text { Ярий } \\
\text { ячмінь, } \\
\text { соя }\end{array}$ & $\begin{array}{l}\text { Включає середні за рівнем } \\
\text { конкурентоспроможності } \\
\text { й за рівнем привабливості } \\
\text { ринки збуту. }\end{array}$ & $\begin{array}{l}\text { Стратегія стабілізації така: збереження та покращення позицій, збіль- } \\
\text { шення конкурентоспроможності продукції шляхом проведення марке- } \\
\text { тингових досліджень, покращення якості продукції, налагодження нових } \\
\text { каналів збуту, продаж через мережу власних магазинів, проведення } \\
\text { рекламних кампаній. }\end{array}$ \\
\hline $\begin{array}{c}\text { Озима } \\
\text { пшениця }\end{array}$ & $\begin{array}{l}\text { Середня привабливість } \\
\text { ринку та низька } \\
\text { конкурентоспроможність } \\
\text { продукту. }\end{array}$ & $\begin{array}{l}\text { Стратегія розвитку така: оцінювання потенціалу задля покращення } \\
\text { виробничого процесу для зниження собівартості та підвищення якості } \\
\text { продукції, перегляд політики збуту, дослідження ринку та основних кон- } \\
\text { курентів. }\end{array}$ \\
\hline
\end{tabular}

Джерело: розроблено автором 
і мати можливість коригувати собівартість органічної продукції, яка є основою процесу ціноутворення. Крім того, на виробництві органічної продукції часто спостерігаються випадки порушення екологічних нормативів, оскільки здійснити точну перевірку за всіма показниками агровиробник не завжди має можливість.

Ми розуміємо, що під час встановлення ціни на органічну продукцію необхідно враховувати інтереси виробників аграрної продукції та збільшувати обсяги її виробництва відповідно до зростаючого попиту на неї.

Досліджуючи питання ціноутворення, О.С. Кільчицька стверджує, що чим більше частка постійних витрат у базисному виторзі від реалізації, тим більше приріст прибутку, що забезпечується за рахунок збільшення обсягу реалізації продукції. Якщо підвищення попиту на продукцію підприємства дає змогу збільшувати й ціни, й натуральний обсяг продажів, то з фінансової точки зору виробнику вигідніше збільшувати ціни, ніж нарощувати натуральний обсяг продажів [4, с. 235].

Розглядаючи тенденції розвитку каналів збуту органічної продукції, Україна може використати європейський досвід, де споживачі купують органічну продукцію безпосередньо у фермерів. Це $€$ вигідним і для самих виробників аграрної продукції, тому що не допускає можливості спекулятивних надбавок переробними підприємствами та торговельними організаціями.

Ще одним каналом $€$ продаж органічної продукції через мережу супермаркетів. Такі країни, як Швейцарія й Австрія, є першими, де було запропоновано продаж органічної продукції у великих супермаркетах разом зі звичайними продуктами. Продаж через мережу спеціалізованих магазинів набула особливої популярності в Німеччині та Нідерландах. Прямі канали товарного просування користуються найбільшою популярністю у Франції та Бельгії.

Представимо схему основних каналів розподілу органічної продукції в Україні (рис. 2).

Найбільш прибутковим для виробників органічної продукції є прямий продаж. Однак його основними недоліками є охоплення невеликої кількості споживачів та охоплення ринку на регіональному рівні. Під час продажу за телефоном і через інтернет-магазини виробник стикається 3 недовірою

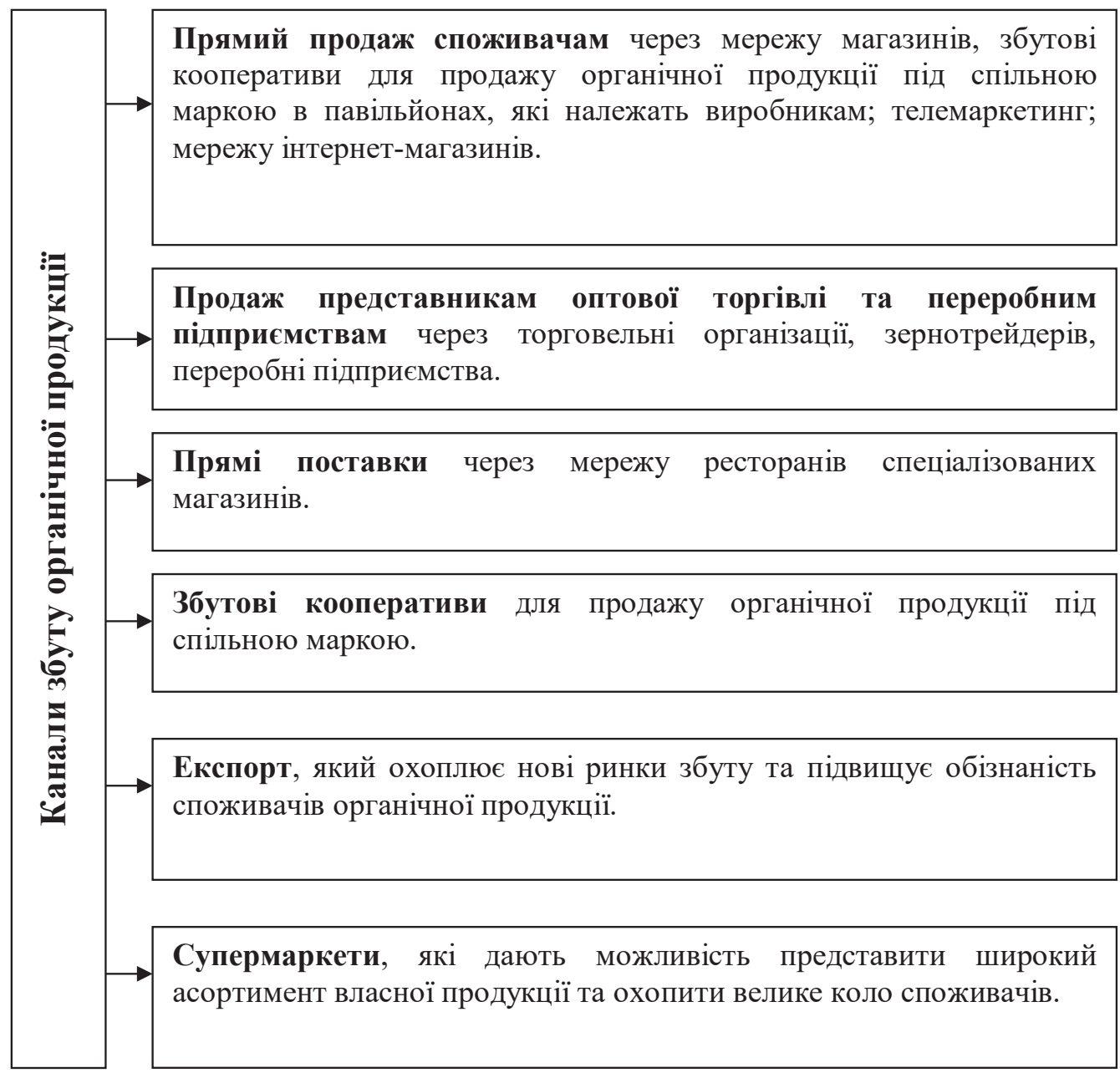

Рис. 2. Основні канали розподілу органічної продукції 
споживачів щодо придбання продукції в такий спосіб, а також обмеженими можливостями споживачів.

Продаж представника оптової торгівлі значно знижує контроль над збутом і послаблює контакт виробника зі споживачем.

Нові можливості для виробників органічної продукції надають створені збутові кооперативи завдяки об'єднанню досвіду, знань і навичок усіх його учасників. Вони можуть допомогти більш швидкому виходу на ринок органічної продукції, охопленню більшого сегменту ринку, сприяти збільшенню кількості потенційних споживачів.

Прямі поставки до спеціалізованих магазинів і ресторанів значно обмежують появу нових споживачів і не дають можливості навіть спробувати купувати продукцію з цікавості [5, с. 42].

Продаж через мережу супермаркетів майже не дає можливості отримати консультацію споживачу, порушують зв'язок споживача з виробником, а ще однією загрозою $є$ велика ймовірність купити в супермаркеті «псевдоорганічну» продукцію. В багатьох супермаркетах органічні продукти часто виставлені серед звичайних, що ускладнює їх пошук споживачем. На нашу думку, дуже важливо органічну продукцію виділяти в окремі відділи й супроводжувати інфрормаційними матеріалами.

Нині недосконалими $€$ всі елементи ринку органічної продукції. Розширення можливостей для реалізації органічної продукції дасть змогу збільшити обсяги ії виробництва, розширити асортимент та знизити ціну.

Аналізуючи потенційні канали збуту органічної продукції, виробник має враховувати вплив мотиваційних фракторів на споживача під час здійснення ним процесу купівлі. Без досконалого знання мотивації екологічно орієнтованої поведінки споживачів неможливо реалізувати екологічну продукцію.

Зауважимо, що під час реалізації вже органічної сільськогосподарської продукції перед аграрними підприємствами постає низка економічних проблем, зокрема:

- недостатня інформованість про ринки органічної продукції; низькі реалізаційні ціни та низький споживчий попит;

- складність організувати виробничий процес у часі таким чином, щоби максимально відповідати потребам ринку;

- високий рівень конкуренції на ринку;

- відсутність впевненості у вчасному виконанні угод, що перешкоджає налагодженню довгострокових стосунків із партнерами;

- недостатня кількість ефективно організованих оптових ринків органічної продукції у великих містах та біржової торгівлі, незначна кількість приватних оптовиків у збутових мережах та закупівельних організацій;

- обмежений доступ до конкурентних пропозицій щодо постачання продукції та нерозвинена інфр- раструктура, яка може забезпечити збереження належної якості органічної продукції, зокрема відповідне транспортування, складування, оброблення, пакування.

Для усунення цих проблем необхідно вжити стратегічно спрямований комплекс заходів щодо формування політики розподілу, а також застосувати сучасні моделі й методи організації, планування та контролю за збутовою діяльністю підприємства.

Просування екологічно чистої продукції на ринок $є$ важливим елементом комплексу маркетингу [6, с. 39]. Для успішного здійснення процесу просування важливими $€$ впевненість і довіра споживача до того, що цей продукт є справді екологічно безпечним.

Відповідно, основними завданнями комунікаційної політики в екологічному маркетингу є:

- формування попиту на екологічно чисту продукцію;

- стимулювання збуту екологічно чистої продукції, поширення на практиці енерго- та ресурсозберігаючих технологій, способів сортування й перероблення відходів;

- інорормування суспільства про дотримання організацією екологічних вимог під час вирощування, перероблення, пакування, перевезення продукції;

- фрормування позитивного іміджу підприємства щодо виконання ним екологічних вимог національних та міжнародних стандартів;

- мотивація споживачів, актуалізація їхніх потреб шляхом роз'яснення наявних ризиків споживання продукції, що не $є$ екологічно безпечною та містить харчові добавки, стабілізатори, барвники тощо;

- роз'яснення споживачам сутності екологічного маркування, наявності в організації системи екологічного менеджменту.

Оскільки більшість підприємств не має у своєму розпорядженні складські приміщення й достатню кількість оборотних коштів на проведення таких агротехнічних операцій, як газація, обеззаражування, охолодження, виробники зернових культур реалізують продукцію відразу після виробництва. Це $є$ причиною перенасиченості ринку зерна у серпні, що приводить до сезонного зниження ціни й попиту на пшеницю. Саме відсутність потужностей для зберігання є причиною реалізації продукції відразу після ії виробництва й обмежує можливості реалізації продукції протягом року. Проблема зберігання продукції $є$ характерною для багатьох підприємств.

Для вдосконалення збутової політики особливу увагу слід приділити умовам очищення, сортування, сушіння та зберігання зерна. Якісно проведені ці технологічні операції дадуть змогу підвищити якість зерна, внаслідок чого підвищиться конкурентоспроможність продукції. Під час перероблення завдяки 
сучасним та традиційним натуральним технологіям органічна продукція зберігає свою безпечність, натуральний склад, поживні властивості, гарні смакові якості, а також не містить синтетичних ароматизаторів, консервантів, харчових добавок та пакується в натуральні матеріали. Зберігання зерна на значний термін дасть змогу реалізувати продукцію за більш вищими ринковими цінами, ніж відразу у післязбиральний термін.

Ми впевнені, що найбільш вигідно зберігати зерно за рахунок власних потужностей шляхом придбавання необхідної техніки та обладнання. За рахунок зберігання аграрне підприємство матиме змогу реалізовувати органічну продукцію за найбільш вигіднішою ціною.

Таким чином, за впровадження концепції екологічного маркетингу екологічно орієнтований комплекс маркетингу в аграрному виробництві включає формування методів ціноутворення, розбудову ринкової інфраструктури, оптимізацію витрат на виробництво органічної продукції за умов державної підтримки виробників аграрної продукції, розширення каналів реалізації та засобів просування органічної продукції, роблячи ії̈ більш доступною для споживача як за ціновим, так і за просторовим фракторами. Забезпечення балансу між економіч ними та природоохоронними інтересами є однією 3 цілей впровадження екологічного маркетингу в аграрному виробництві.

Висновки 3 проведеного дослідження. Ми переконані, що аграрні підприємства мають розпочати процес переходу на органічне виробництво, а замовляти сертифікацію варто тільки за наявності обґрунтованої маркетингової стратегії збуту органічної продукції та ринкового зростання аграрного підприємства.

Слід впроваджувати екологічно орієнтований комплекс маркетингу, який включає фрормування методів ціноутворення, розбудову ринкової інфраструктури, оптимізацію витрат на виробництво органічної продукції за умов державної підтримки виробників, розширення каналів реалізації та засобів просування органічної продукції й залежить від впливу зовнішніх та внутрішніх фракторів, виду продукції та мотивування споживачів. Всі елементи екологічно орієнтованого комплексу маркетингу мають бути взаємоузгоджені, адаптовані та доповнені з урахуванням екологічних вимог, потреб потенційних споживачів, технологічних особливостей екологічно безпечного виробництва аграрної продукції та специсріки самої концепції екологічного маркетингу, що дасть змогу зробити органічну продукцію доступною для споживача за ціновим та просторовим фракторами.

Встановлено, що процес фрормування ціни на органічну продукцію має враховувати особливості попиту, пропозиції, рівень конкуренції, а також інтереси виробників продукції. Ціна має сприяти розвитку аграрних підприємств під час переходу від традиційного до органічного виробництва, як наслідок, розширювати обсяги виробництва органічної продукції. Впровадження концепції екологічного маркетингу забезпечить вироблення продукції високої якості, що, відповідно, буде супроводжуватися підвищенням її собівартості та ціни. Собівартість органічної продукції здебільшого перевищує собівартість традиційної продукції, хоча можливі й винятки залежно від виду продукції, сезону та регіону.

Обґрунтовано нові підходи маркетингової збутової політики аграрних підприємств 3 виробництва органічної продукції, які засновані на переорієнтації до потреб ринку. Запропоновано більш прогресивні фрорми збуту, такі як активна діяльність виробників органічної продукції на оптових ринках; прямий продаж екологічних товарів високої якості за принципами ексклюзивного розподілу та із залученням спеціалізованих посередників; створення нових маркетингових структур, а саме вертикально й горизонтально інтегрованих маркетингових системи та кооперативів. Інтегрована взаємодія з державними органами й переробними підприємствами дасть змогу підвищити інновації та інвестиції у виробництво органічної продукції.

Отже, в більшості аграрних підприємств вже відбувся процес переосмислення ролі економічних та екологічних пріоритетів, а очевидна перевага була віддана екологічно орієнтованому розвитку. Ми впевнені, що принципи й складові екологічного маркетингу мають бути імплементовані у діяльність більшості аграрних підприємств.

\section{БІБЛІОГРАФІЧНИЙ СПИСОК:}

1. Шкуратов O.І., Воронецька І.С. Використання інструментів екологічного маркетингу в господарській діяльності аграрних підприємств. Економіка природокористування i охорона навколишнього середовища. 2012. Ч. 2. С. 214-218 (дата звернення: 15.05.2019)

2. Global Organic Market Access (GOMA). A project of FAO, IFOAM and UNCTAD. URL: http:// www.goma-organic.org/about/project (дата звернення: 19.09.2019).

3. Томашевська О.А. Органічне виробництво в світі: реалії та перспективи. Інноваційна економіка. 2013. № 6. С. 161-164 (дата звернення: 02.07.2019).

4. Кільніцька О.С. Методи фрормування моделі ціни органічної сільськогосподарської продукції. Збірник праць Таврійського державного агротехнологічного університету. 2014. Т. 4(18). С. 231-240 (дата звернення: 10.10.2019).

5. Чудовська В.А. Фактори фрормування вітчизняного ринку органічної сільськогосподарської продукції. Агросвіт. 2012. № 18. С. 40-44 (дата звернення: 20.11.2019).

6. Шумейко О.В. Органічне агровиробництво України: тенденції розвитку та виклики інституціонального забезпечення. Вісник THEУ. 2016. № 2. С. 33-42 (дата звернення: 10.12.2019). 


\section{REFERENCES:}

1. Shkuratov O.I., Voroneczka I.S. (2012). Vykorystannya instrumentiv ekologichnogo marketyngu $\checkmark$ gospodarskij diyalnosti agrarnyx pidpryemstv [Use of environmental marketing tools in agricultural enterprises of economic activities]. Environmental Economics and Environmental Protection, no. 2, pp. 214-218 (in Ukrainian) (accessed: 15 May 2019).

2. Global Organic Market Access (GOMA). A project of FAO, IFOAM and UNCTAD [Electronic resource]. Access mode: http://www.goma-organic.org/about/project (accessed: 19 September 2019).

3. Tomashevska O.A. (2013). Organichne vyrobnycztvo v sviti: realiyi ta perspektyvy [Organic production in the world: realities and prospects]. Innovative economy, no. 6, pp. 161-164. (in Ukrainian) (accessed: 02 July 2019).
4. Kilniczka O.S. (2014). Metody formuvannya modeli ciny organichnoyi silskogospodarskoyi produkciyi [Methods of formation of price model for organic agricultural products]. Proceedings of the Taurida State Agrotechnological University, vol. 4(18), pp. 231-240 (in Ukrainian) (accessed: 10 October 2019).

5. Chudovska V.A. (2012). Faktory formuvannya vitchyznyanogo rynku organichnoyi silskogospodarskoyi produkciyi [Factors of formation of the domestic market of organic agricultural products]. Agrosvit, no. 18, pp. 40-44 (in Ukrainian) (accessed: 20 November 2019).

6. Shumejko O.V. (2016). Organichne agrovyrobnycztvo Ukrayiny: tendenciyi rozvytku ta vyklyky instytucionalnogo zabezpechennya [Organic agricultural production in Ukraine: development trends and challenges of institutional support]. Bulletin TNEU, no. 2, pp. 33-42 (in Ukrainian) (accessed: 10 December 2019). 